\title{
Germination of quinoa seeds prevenient from agroecological and conventional crop systems
}

\author{
Cristiani Belmonte, Edmar Soares de Vasconcelos, Eloisa Lorenzetti, Alexandra da Silva Martinez, Renan

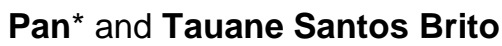

Unioeste University, Marechal Cândido Rondon, PR, Brazil

*Author for correspondence: renanpan45@hotmail.com

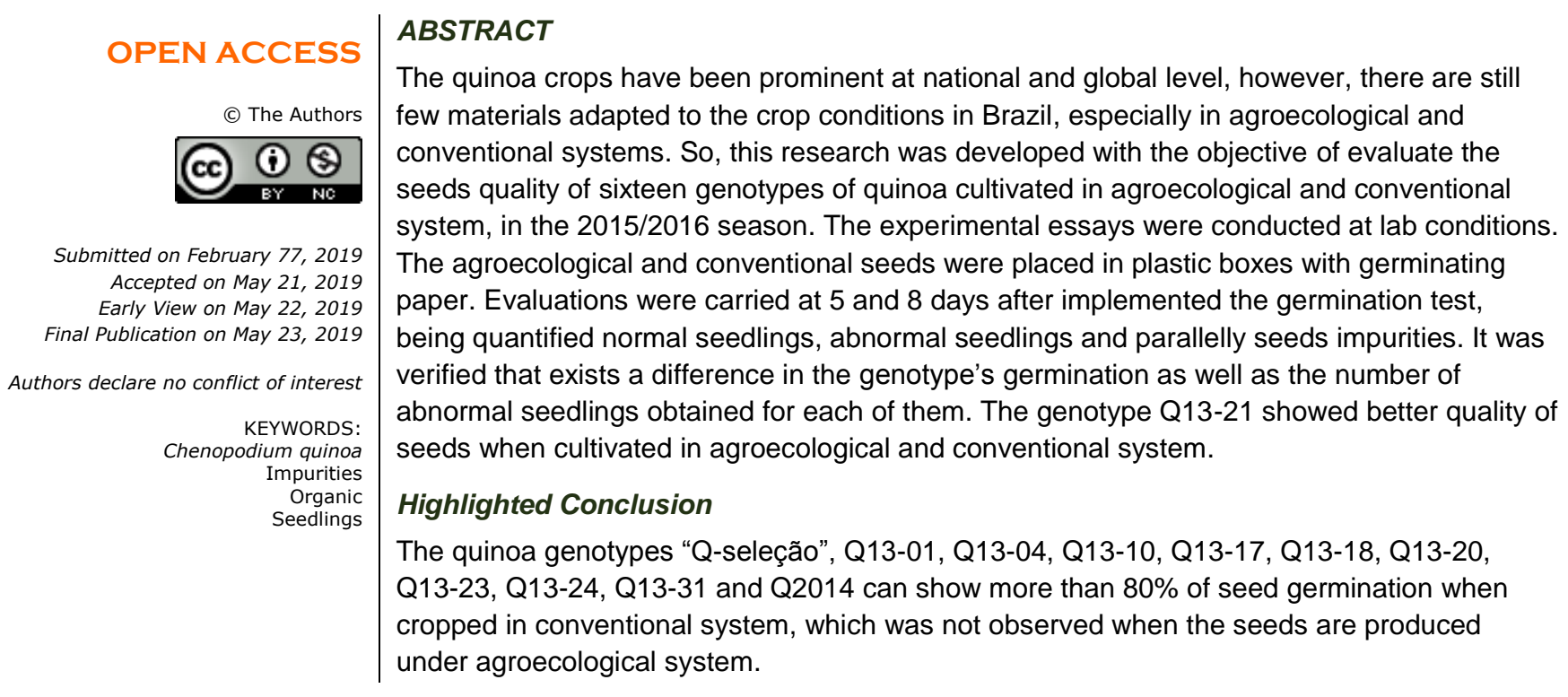

\section{INTRODUCTION}

Native to Andean regions, quinoa (Chenopodium quinoa Wild.) belongs to Amaranthaceous family, Chenopodiaceous subfamily (APG III 2009). Due to its characteristics such as high genetic variability and good adaptability to a large scale of crop conditions, being it organic or conventional (Pulvento et al. 2010), the interest in the quinoa crop is increasing and the studies have intensified in the last decade around the world (Rosa et al. 2009; Christiansen et al. 2010; Sun et al. 2014; Peterson and Murphy 2015).

The culture is frequently called as a pseudo-cereal, which grains have higher nutritional value than the traditional cereals (Repo-Carrasco-Valencia et al. 2010), and its composition presents excellent equilibrium between oil, protein and fat contents (Vega-Gálvez et al. 2010).

The total protein present in the quinoa grains (11.0-15.0\%), higher than that found in rice (8.5\%) and maize $(10.3 \%)$, allied to low glycemic index and gluten absence benefits diabetic patients, celiac and lactose intolerant (James 2009), a fact evidenced by the recent research carried out, attesting the nutritional properties of this grain (Jacobsen and Christiansen 2016; Nowak et al. 2016).

Its seeds, described as tiny and flat, have no dormancy being also highly hygroscopic (Bhargava et al. 2007). Therefore, when exposed to moisture they are capable of germinating in a short amount of time, about 6 to 10 hours (Souza et al. 2016). Such characteristics make necessary the seeds' adequate storage to avoid deteriorations due to moisture and temperature, as well as bugs and microorganism action, in order to preserve the seeds' genetic properties until the moment of sowing (Ceccato et al. 2011).

It is essential that seed intended for sowing is the highest quality in relation to purity, germination and viable seedlings formation. Therefore, the obtainment of quality seed is one of the most important stages in the quinoa production, because it influences on the success and crop establishment, and it is related to many factors, among them are genetic aspects and cultivation systems (Spehar et al. 2015). 
The national grain production is directly related to the conventional system, however, the organic cultivation is constantly growing in the Brazilian agricultural system, as the market of food produced without agrochemicals or mineral fertilizers have increased around the world (Silva et al. 2012).

Few researches are related to the cultivation system and seeds quality and, also, researches related to quinoa germination are still incipient, so much so that there are no recommendations for the germination test in the Norms for Seed Analysis, as well as there are no publications that standardize this test methodology to quinoa (Brasil 2009; Strenske et al. 2015).

The present study was carried out with the objective of evaluating the influence of the agroecological and conventional production systems over germination, seedlings formation and seeds purity of sixteen genotypes of Chenopodium quinoa, cultivated in the agricultural year of 2015/16 in Entre Rios do Oeste - PR.

\section{MATERIAL AND METHODS}

In this study the experimental essays were carried at lab conditions. We used seeds of 16 genotypes (Q12-23, Q13-01, Q13-02, Q13-03, Q13-04, Q13-06, Q13-07, Q13-10, Q13-17, Q13-18, Q13-20, Q13-21, Q13-24, Q13-31, "Q-seleção" and Q2014) cultivated in the agricultural year of 2015/16, under two management systems (agroecological and conventional), at the experimental station Professor Alcebíades Luiz Orlando, in Entre Rios do Oeste city - PR.

The area destined to agroecological cultivation was ploughed once and harrowed twice before sowing and, at sowing, was placed $250 \mathrm{~kg} \mathrm{ha}^{-1}$ of earthworm humus $5 \mathrm{~cm}$ bellow the seeds, preconizing the agroecological principles. Two hoeing were carried out to control weeds, the first when the crop had three completely expanded leaves and the second at the beginning of flowering. In order to minimize the risk of insect attack, as performed and application of neem oil at plants flowering, since the area has been cultivated for three years without any application of agrochemicals.

The quinoa sowing, in the conventional system, was performed over the maize straw. At the sowing moment, placement fertilization at the dose of $250 \mathrm{~kg} \mathrm{ha}^{-1}$ of the commercial formula NPK 02-20-20 was performed $5 \mathrm{~cm}$ bellow the seeds. A hoeing was performed when the crop had three expanded leaves and, at flowering, one application of commercial product "Engeo Pleno" $\left(150 \mathrm{~mL} \mathrm{ha}^{-1}\right)$ to control stink bug and Spodoptera frugiperda present in the area.

Harvest was carried manually at physiological maturation with scythe, cutting the stem below the insertion of the first panicle, putting into plastic bags according to each experimental unit, the materials were placed to sun dry for three days, been them covered with a plastic tarp at the end of the evening and uncovered at the beginning of the morning. Then all the materials were manually threshed with a wood section to hit the bags with the plants for several times, making it possible to remove the grains from the panicles and separate them from the other parts of the plants.

Next, pre-cleaning was performed separating the bigger parts from the plants (stems, branches), and the remaining material was sieved with $4 \mathrm{~mm}$ sieve, ABNT/ASTM 5, separating the larger impurities and a final cleaning with $1 \mathrm{~mm}$ sieve, ABNT/ASTM 18, separating the smaller impurities, which were stored in paper envelope under controlled environmental conditions, average temperature of $20{ }^{\circ} \mathrm{C}$ and relative humidity of $30 \%$, in germination chamber at lab conditions.

The experimental design had three replicates with 50 seeds each, being distributed over germination paper Germiteste ${ }^{\circledR}$ in plastic boxes $(11 \times 11 \times 3.5 \mathrm{~cm})$, which were stored in germination chambers with constant temperature of $25^{\circ} \mathrm{C}$ without photoperiod. The experiment was implemented at 07, 08 and 09/12/2016.

The impurity determinations were made with precision scale, putting $1 \mathrm{~g}$ of material of each genotype and, posteriorly, the impurities were separated to carry a new weighing.

The evaluations for normal seedlings, abnormal seedlings and germinated seeds were carried in the $5^{\text {th }}$ and $8^{\text {th }}$ day after the date when the germination test was implemented.

For the germination test seeds were disposed over two sheets of germinative paper inside plastic boxes with a spacing between seeds of $1 \mathrm{~cm}$.

The group of experimental data was submitted to variance analysis and performed the means comparison by the Tukey test with the computational software Genes (Cruz 2013).

\section{RESULTS AND DISCUSSION}

The experiment was evaluated at 5 and 8 days showing good experimental precision indexes (Tables 1 and 2), with variation coefficients lower than the observed by Strenske et al. (2015) for seed germination of quinoa, indicating lower random variations in the experimental data. 
Table 1. Variance analysis for impurities in the quinoa seeds cultivated in agroecological and conventional system in Entre Rios do Oeste in the agricultural year of 2015/16.

\begin{tabular}{lcc}
\hline Variation source & DF & Impurities \\
\cline { 3 - 3 } & & MS \\
\hline Crop System (CS) & 1 & $0,6581^{* *}$ \\
Benotypes (G) & 15 & $0.0151^{\star *}$ \\
Interaction CS x G & 2 & $0.0008^{\text {ns }}$ \\
Residual & 15 & $0.0090^{\star *}$ \\
\hline Average & 56 & 0.0027 \\
VC (\%) & & 0.3704 \\
\hline
\end{tabular}

${ }^{\text {** }}$ significant at $0.01 ;{ }^{\text {ns }}$ non-significant, by the $\mathrm{F}$ test.

Table 2. Conjunct variance analysis for the germination data of quinoa seeds cultivated in agroecological and conventional system, in Entre Rios do Oeste in the agricultural year of 2015/16.

\begin{tabular}{|c|c|c|c|c|}
\hline \multirow[t]{2}{*}{ Variation Sources } & \multirow[t]{2}{*}{ DF } & Normal seedlings & Abnormal seedlings & 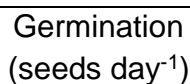 \\
\hline & & AS & AS & AS \\
\hline Crop system (CS) & 1 & $116,749^{* *}$ & $430.48^{* *}$ & $103.001^{\star *}$ \\
\hline Genotype (G) & 15 & $2.675^{\star *}$ & $28.28^{*}$ & $2.695^{\star \star}$ \\
\hline Day (D) & 1 & $1.527^{\star *}$ & $13.70^{\mathrm{ns}}$ & $1.251^{* *}$ \\
\hline Blocks & 2 & $856^{\star *}$ & $110.87^{\star \star}$ & $928^{* *}$ \\
\hline Interaction CS x G & 15 & $1.822^{\star *}$ & $137^{\star \star}$ & $1.722^{\star \star}$ \\
\hline Interaction CS x D & 1 & $84^{\mathrm{ns}}$ & $3.64^{\mathrm{ns}}$ & $123^{\text {ns }}$ \\
\hline Interaction $\mathrm{G} \times \mathrm{D}$ & 15 & $5^{\text {ns }}$ & $2.19^{n s}$ & $4^{\mathrm{ns}}$ \\
\hline Interaction $\mathrm{CS} \times \mathrm{G} \times \mathrm{D}$ & 15 & $10^{\text {ns }}$ & $3.24^{\mathrm{ns}}$ & $10^{\text {ns }}$ \\
\hline Residual & 474 & 110 & 14.08 & 96 \\
\hline Average & & 59.2003 & 10.1907 & 69.4042 \\
\hline VC (\%) & & 17.72 & 36.82 & 14.12 \\
\hline
\end{tabular}

${ }^{* *}$ significant at $0.01 ;{ }^{*}$ significant at $0.05 ;{ }^{\text {ns }}$ non-significant, by the $\mathrm{F}$ test.

Significant differences $(p<0.01)$ exist for impurities in the interaction of genotype and cultivation system (Table 1 ), showing that the genotypes differed among themselves when cultivated in agroecological and conventional systems, possibly due to the tolerance, or not, to non-controllable factors in the different cropping systems.

By the variance analysis was verified an interaction between the cultivation system and the genotypes $(p<0.01)$ for all parameters tested (Table 2) suggesting different behaviors from the genotypes when submitted to the agroecological or conventional crop system, implying changes in the seeds quality of one genotype and allowing the selection of distinct genotypes for agroecological or conventional crop system.

The effect of the evaluation day was significant $(p<0.01)$ for parameters normal seedlings, abnormal seedlings and germinated seeds, indicating that such characteristics were influenced by the days when the evaluations were made (Table 2). The first count allows to observe the percentage of initial germination, so that the evaluation at five days was not enough to detect the germination of all seeds with germination potential.

Seeds from the genotypes Q13-03 and Q13-01 from the agroecological system had the highest impurity index (Table 3), that is, presented a higher amount of impurities with the seeds. In the seeds cleaning process after threshed, sieves were used to separate impurities, not been possible to separate the residuals with the same size as the quinoa seeds. Because of this, part of the unfertilized flowers, without grain formation, stayed with the seeds, increasing their impurity levels.

The seeds non-formation may be related to the incidence and the attack of stink bugs to the quinoa crop, mostly attracted by the calcium oxalate present in the panicles. However, it is not possible to infer if the highest index of impurities in the seeds from the agroecological system is due to the bugs attack, once was not quantified and evaluated the attacks from the stink buts to the crop.

The genotypes Q13-23 and Q13-07 showed impurities index smaller than the genotypes Q13-03 and Q13-01. The genotype Q13-02 had the highest impurity index in the seeds obtained from the conventional cultivation, being its index equal to the obtained from the seeds cultivated in the agroecological system. Seeds from genotypes Q1318 and Q13-21 produced in the conventional system showed a smaller impurity index than the seeds from the genotypes Q13-02, Q13-06 and Q13-20 (Table 3), which can lead to the high quality of the seeds coming from the conventional planting for these genotypes. 
Table 3. Impurities index of quinoa seeds cultivated in agroecological and conventional system in Entre Rios do Oeste in the agricultural year of 2015/16.

\begin{tabular}{|c|c|c|}
\hline \multirow{2}{*}{ Genotypes } & \multicolumn{2}{|c|}{ Impurities } \\
\hline & Agroecological & Conventional \\
\hline Q-seleção & $0.4640 \mathrm{~A}$ abc & 0.2973 B abcd \\
\hline Q13-21 & $0.3830 \mathrm{~A} \mathrm{bc}$ & $0.2063 \mathrm{~B} \mathrm{~d}$ \\
\hline Q13-02 & $0.4860 \mathrm{~A} a b c$ & $0.4360 \mathrm{~A} \mathrm{a}$ \\
\hline Q13-03 & $0.5290 \mathrm{~A} \mathrm{ab}$ & $0.3400 \mathrm{~B}$ abcd \\
\hline Q13-06 & $0.4983 \mathrm{~A} a b c$ & $0.3857 \mathrm{~B} a b$ \\
\hline Q13-17 & $0.5010 \mathrm{~A} a b c$ & $0.2500 \mathrm{~B} \mathrm{bcd}$ \\
\hline Q13-01 & $0.5765 \mathrm{~A} \mathrm{a}$ & $0.2773 \mathrm{~B}$ bcd \\
\hline Q13-23 & $0.3703 \mathrm{~A} \mathrm{C}$ & $0.3047 \mathrm{~A}$ abcd \\
\hline Q13-24 & $0.5110 \mathrm{~A} a b c$ & $0.2300 \mathrm{~B} \mathrm{~cd}$ \\
\hline Q13-07 & $0.3735 \mathrm{Ac}$ & $0.3193 \mathrm{~A}$ abcd \\
\hline Q13-18 & $0.4063 \mathrm{~A} \mathrm{bc}$ & $0.2003 \mathrm{~B} \mathrm{~d}$ \\
\hline Q13-10 & $0.3785 \mathrm{~A} \mathrm{bc}$ & $0.2220 \mathrm{~B} \mathrm{~cd}$ \\
\hline Q13-04 & $0.4860 \mathrm{~A} a b c$ & $0.2617 \mathrm{~B} \mathrm{bcd}$ \\
\hline Q13-20 & $0.4417 \mathrm{~A} a b c$ & $0.3680 \mathrm{~A} a b c$ \\
\hline Q13-31 & $0.4440 \mathrm{~A}$ abc & $0.2173 \mathrm{~B} \mathrm{~cd}$ \\
\hline Q2014 & $0.4647 \mathrm{~A} a b c$ & $0.2223 \mathrm{~B} \mathrm{~cd}$ \\
\hline Average & 0.4571 & 0.2836 \\
\hline
\end{tabular}

The group of genotypes Q13-24, Q13-18, Q13-10, Q2014 and Q13-01 showed higher percentage of normal seedlings when cultivated in the conventional system (Table 4), similar performance to the observed in the germination test. However, the agroecological seeds from this group of genotypes had inverse behavior in the two counts, with low rates of normal seedlings. Such result may be a reflection of the non-adaptation of these genotypes to the agroecological system and, or the presence of impurities coming from its production process, with highlight to Q13-01, which was surpassed for higher number of genotypes to about the number of emerged seedlings.

Table 4. Percentage of normal seedlings at 5 and 8 days after implemented the germination test of quinoa seeds cultivated in agroecological and conventional system, in Entre Rios do Oeste in the agricultural year of 2015/16.

\begin{tabular}{|c|c|c|c|c|}
\hline \multirow{2}{*}{ Genotypes } & \multicolumn{2}{|c|}{5 Days } & \multicolumn{2}{|c|}{8 Days } \\
\hline & Agroecological & Conventional & Agroecological & Conventional \\
\hline Q-seleção & $46.22 \mathrm{~B} \mathrm{bcd}$ & $74.00 \mathrm{~A}$ abc & 50.22 B bcd & $76.66 \mathrm{~A}$ ab \\
\hline Q13-21 & $70.88 \mathrm{~B} \mathrm{a}$ & $81.33 \mathrm{~A} a b$ & $74.44 \mathrm{~A} \mathrm{a}$ & $83.33 \mathrm{~A}$ a \\
\hline Q13-02 & 36.33 A cde & $35.77 \mathrm{~A} \mathrm{~d}$ & $38.00 \mathrm{~A}$ de & $39.55 \mathrm{~A} \mathrm{C}$ \\
\hline Q13-03 & $33.00 \mathrm{~B}$ de & $66.44 \mathrm{~A} \mathrm{bc}$ & $35.00 \mathrm{~B}$ de & $71.11 \mathrm{~A} a b$ \\
\hline Q13-06 & $46.00 \mathrm{~B}$ bcd & $60.88 \mathrm{~A} \mathrm{C}$ & 51.33 B bcd & $64.88 \mathrm{~A} \mathrm{~b}$ \\
\hline Q13-17 & $34.00 \mathrm{~B}$ de & $73.77 \mathrm{~A} a b c$ & $35.66 \mathrm{~B}$ de & $75.11 \mathrm{~A} a b$ \\
\hline Q13-01 & $27.00 \mathrm{~B} \mathrm{e}$ & $70.66 \mathrm{~A} a b c$ & $32.00 \mathrm{~B} \mathrm{e}$ & $73.11 \mathrm{~A} \mathrm{ab}$ \\
\hline Q13-23 & $51.77 \mathrm{~B} \mathrm{bc}$ & $78.44 \mathrm{~A} a b$ & $56.22 \mathrm{~B} \mathrm{bc}$ & $80.66 \mathrm{~A} a b$ \\
\hline Q13-24 & 36.00 B cde & $84.66 \mathrm{~A} \mathrm{a}$ & 42.44 B cde & $87.11 \mathrm{~A} \mathrm{a}$ \\
\hline Q13-07 & $59.66 \mathrm{~B} a b$ & $71.55 \mathrm{~A} a b c$ & $63.66 \mathrm{~A} a b$ & $73.33 \mathrm{~A} a b$ \\
\hline Q13-18 & 40.22 B cde & $85.33 \mathrm{~A} \mathrm{a}$ & 44.88 B cde & $87.11 \mathrm{~A} \mathrm{a}$ \\
\hline Q13-10 & 41.66 B cde & $82.00 \mathrm{~A} a b$ & 45.33 B cde & $84.22 \mathrm{~A} \mathrm{a}$ \\
\hline Q13-04 & $33.66 \mathrm{~B}$ de & $76.66 \mathrm{~A} a b c$ & 41.00 B cde & $79.33 \mathrm{~A} \mathrm{ab}$ \\
\hline Q13-20 & 48.88 B bcd & $66.00 \mathrm{~A} \mathrm{bc}$ & 51.11 B bcd & $71.33 \mathrm{~A} \mathrm{ab}$ \\
\hline Q13-31 & $32.22 \mathrm{~B}$ de & $79.55 \mathrm{~A} a b$ & $36.88 \mathrm{~B}$ de & $81.77 \mathrm{~A} a b$ \\
\hline Q2014 & $36.88 \mathrm{~B}$ cde & $79.77 \mathrm{~A} a b$ & 40.66 B cde & $80.22 \mathrm{~A} a b$ \\
\hline Average & 42.14 & 72.92 & 46.17 & 75.55 \\
\hline
\end{tabular}

* Means followed by the same uppercase letters in the row and lower-case letters in the column do not differ statistically by the Tukey test $(p<0.05)$.

At five days was verified that the number of normal seedlings for the genotype Q13-2 produced in the conventional system was superior to the ones from agroecological, whilst in the second count (at 8 days), the seeds did not differ statistically (Table 4). It may be related to the condition that the seeds were when obtained from 
the agroecological crop system, for this genotype, presenting lower vigor than the ones produced in the conventional system.

The low percentage of normal seedlings observed for the genotype Q13-02 at 5 days remained at 8 days, both for organic seeds and conventional seeds (Table 4), which may be an indication that the crop system adopted was not a determinant factor in the seeds' quality for this genotype.

On both counts performed, it is observed that the genotypes Q13-23 and Q13-18 presented higher values for abnormal plants from the seeds obtained from the agroecological system if compared to the verified in the seeds obtained from the conventional crop (Table 5). In the seeds obtained from the conventional crop of genotypes Q1317 and Q13-20, higher amounts of abnormal plants at 8 days were observed when compared to the genotype Q1318 (Table 5). The percentage of abnormal seedlings originated from the agroecological seeds was similar to the conventional system, such behavior may be considered an indication that these materials can be used in agroecological systems without loss to the formation of a plant stand, and it should be considered the genotypes percentage of germination.

Table 5. Percentage of abnormal seedlings, at 5 and 8 days after implemented the germination test of quinoa seeds cultivated in agroecological and conventional system in Entre Rios do Oeste in the agricultural year of 2015/16.

\begin{tabular}{|c|c|c|c|c|}
\hline \multirow{2}{*}{ Genotypes } & \multicolumn{2}{|c|}{5 Days } & \multicolumn{2}{|c|}{8 Days } \\
\hline & Agroecological & Conventional & Agroecological & Conventional \\
\hline Q-seleção & $12.00 \mathrm{~A}$ abcd & $9.33 \mathrm{~A} a b c$ & $11.33 \mathrm{~A} a b c$ & $8.66 \mathrm{~A} a b$ \\
\hline Q13-21 & 10.44 A bcd & $9.55 \mathrm{~A} a b c$ & $9.55 \mathrm{~A} \mathrm{bc}$ & $9.33 \mathrm{~A} a b$ \\
\hline Q13-02 & $9.00 \mathrm{~A} \mathrm{~cd}$ & $9.55 \mathrm{~A} \mathrm{abc}$ & $9.66 \mathrm{~A} \mathrm{bc}$ & $10.22 \mathrm{~A} \mathrm{ab}$ \\
\hline Q13-03 & $11.33 \mathrm{~A} \mathrm{bcd}$ & $9.77 \mathrm{~A} a b c$ & $12.00 \mathrm{~A} \mathrm{abc}$ & $8.44 \mathrm{~B}$ ab \\
\hline Q13-06 & $11.11 \mathrm{~A} \mathrm{bcd}$ & $10.00 \mathrm{~A} a b c$ & $10.88 \mathrm{~A} \mathrm{bc}$ & $9.11 \mathrm{~A} a b$ \\
\hline Q13-17 & $9.33 \mathrm{Acd}$ & $12.44 \mathrm{~A} \mathrm{ab}$ & $10.33 \mathrm{~A} \mathrm{bc}$ & $12.44 \mathrm{~A} \mathrm{a}$ \\
\hline Q13-01 & $8.66 \mathrm{~A} \mathrm{~cd}$ & $9.55 \mathrm{~A} a b c$ & $8.66 \mathrm{~A} \mathrm{bc}$ & $8.88 \mathrm{~A} a b$ \\
\hline Q13-23 & $15.55 \mathrm{~A} a b$ & $7.11 \mathrm{~A} \mathrm{bc}$ & $14.66 \mathrm{~A} \mathrm{ab}$ & $6.66 \mathrm{~B} a b$ \\
\hline Q13-24 & $8.66 \mathrm{~A} \mathrm{~cd}$ & $10.44 \mathrm{~A} a b c$ & $9.55 \mathrm{~A} \mathrm{bc}$ & $9.11 \mathrm{~A} a b$ \\
\hline Q13-07 & $8.00 \mathrm{~A} \mathrm{~d}$ & $7.55 \mathrm{~A} \mathrm{bc}$ & $7.66 \mathrm{Ac}$ & $8.88 \mathrm{~A} a b$ \\
\hline Q13-18 & $18.00 \mathrm{~A} \mathrm{a}$ & $6.22 \mathrm{~B} \mathrm{C}$ & $17.11 \mathrm{~A} \mathrm{a}$ & $6.00 \mathrm{~B} \mathrm{~b}$ \\
\hline Q13-10 & $10.00 \mathrm{~A} \mathrm{bcd}$ & $8.44 \mathrm{~A} \mathrm{abc}$ & $10.33 \mathrm{~A} \mathrm{bc}$ & $7.77 \mathrm{~A} a b$ \\
\hline Q13-04 & $14.66 \mathrm{~A} \mathrm{abc}$ & $8.66 \mathrm{~B} a b c$ & $12.33 \mathrm{~A} \mathrm{abc}$ & $8.44 \mathrm{~B} a b$ \\
\hline Q13-20 & $8.66 \mathrm{~B} \mathrm{~cd}$ & $14.00 \mathrm{~A} \mathrm{a}$ & $8.44 \mathrm{~B} \mathrm{C}$ & $12.22 \mathrm{~A} \mathrm{a}$ \\
\hline Q13-31 & $11.55 \mathrm{~A}$ bcd & $8.88 \mathrm{~A} \mathrm{abc}$ & $11.55 \mathrm{~A} a b c$ & $8.88 \mathrm{~A} a b$ \\
\hline Q2014 & 10.66 A bcd & $12.00 \mathrm{~A} \mathrm{abc}$ & $11.55 \mathrm{~A} a b c$ & $10.88 \mathrm{~A} \mathrm{ab}$ \\
\hline Averages & 11.10 & 9.59 & 10.97 & 9.12 \\
\hline
\end{tabular}

The evaluated genotypes showed superior average to germination when the seeds came from the conventional system. At 5 and 8 days, the genotype Q13-21, when cultivated in conventional system presented a higher number of germinated seeds (Table 6). While in the agroecological production system this genotype had a similar behavior, with higher number of germinated seeds than the others. In research with pumpkin, Casaroli et al. (2006) observed that in one specific variety the physiological potential of its seeds from the conventional system was superior to the one produced in the agroecological system. This fact may be related to the interaction between genotypes and crop systems, when the behavior of one genotype is superior to another in a particular environment and change the performance out of that environment.

The Q13-21 showed better germination rates for agroecological and conventional seeds at 5 days. At 8 days this genotype kept the good performance against the Q-seleção, Q13-02, Q13-03, Q13-06, Q13-17, Q13-01, Q1324, Q13-18, Q13-10, Q13-04, Q13-20, Q13-31 and Q2014 (Table 6), because it excelled independently of the crop system, being possible to be recommended for both crop systems.

It is observed in Table 6 that the agroecological and conventional seeds from the genotype Q13-02 showed lower germination rates at 5 days, demonstrating that the genotype had a lower performance against the other tested materials independently of the crop system, a fact also evidenced at 8 days. In this case the event is credited to the condition that the genotype have to produce seeds with reduced germination power, since both the indicative of vigor (evaluation at 5 days) and germination (evaluation at 8 days) of its seeds are low. 
Table 6. Germination percentage at 5 and 8 days after implemented the germination test of quinoa seeds cultivated in agroecological and conventional system in Entre Rios do Oeste in the agricultural year of 2015/16.

\begin{tabular}{|c|c|c|c|c|}
\hline \multirow{2}{*}{ Genotypes } & \multicolumn{2}{|c|}{5 Days } & \multicolumn{2}{|c|}{8 Days } \\
\hline & Agroecological & Conventional & Agroecological & Conventional \\
\hline Q-seleção & $58.22 \mathrm{~B}$ bcd & $83.33 \mathrm{~A} \mathrm{abc}$ & $61.56 \mathrm{~B} \mathrm{bcd}$ & $85.33 \mathrm{~A} a b c$ \\
\hline Q13-21 & $81.33 \mathrm{~B} \mathrm{a}$ & $90.88 \mathrm{~A} a b$ & $84.00 \mathrm{~A} \mathrm{a}$ & $92.67 \mathrm{~A} \mathrm{ab}$ \\
\hline Q13-02 & 45.33 A de & $45.33 \mathrm{~A} \mathrm{~d}$ & 47.67 A cde & 49.78 A d \\
\hline Q13-03 & $44.33 \mathrm{~B}$ de & $76.22 \mathrm{~A} \mathrm{bc}$ & 47.00 B cde & $79.56 \mathrm{~A} \mathrm{bc}$ \\
\hline Q13-06 & 57.11 B bcd & $70.88 \mathrm{~A} \mathrm{C}$ & $62.22 \mathrm{~B} \mathrm{bc}$ & $74.00 \mathrm{~A} \mathrm{C}$ \\
\hline Q13-17 & $43.33 \mathrm{~B}$ de & $86.22 \mathrm{~A} a b c$ & $46.00 \mathrm{~B}$ de & $87.56 \mathrm{~A}$ abc \\
\hline Q13-01 & $35.66 \mathrm{~B} \mathrm{e}$ & $80.22 \mathrm{~A} a b c$ & $40.67 \mathrm{~B} \mathrm{e}$ & $82.00 \mathrm{~A}$ abc \\
\hline Q13-23 & $67.33 \mathrm{~B}$ abc & $85.55 \mathrm{~A} a b c$ & $70.89 \mathrm{~B} \mathrm{ab}$ & 87.33 A abc \\
\hline Q13-24 & $44.66 \mathrm{~B}$ de & $95.11 \mathrm{~A} \mathrm{a}$ & $52.00 \mathrm{~B}$ cde & $96.22 \mathrm{~A} \mathrm{a}$ \\
\hline Q13-07 & $67.66 \mathrm{~B}$ ab & $79.11 \mathrm{~A} \mathrm{bc}$ & $71.33 \mathrm{~B} \mathrm{ab}$ & $82.22 \mathrm{~A} a b c$ \\
\hline Q13-18 & 58.22 B bcd & $91.55 \mathrm{~A} a b$ & $62.00 \mathrm{~B} \mathrm{bc}$ & $93.11 \mathrm{~A} \mathrm{ab}$ \\
\hline Q13-10 & $51.66 \mathrm{~B} \mathrm{~cd}$ & $90.44 \mathrm{~A} a b$ & 55.67 B bcde & $92.00 \mathrm{~A} \mathrm{ab}$ \\
\hline Q13-04 & $48.33 \mathrm{~B}$ de & $85.33 \mathrm{~A} \mathrm{abc}$ & 53.33 B cde & $87.78 \mathrm{~A} a b c$ \\
\hline Q13-20 & 57.55 B bcd & $80.00 \mathrm{~A} a b c$ & $59.56 \mathrm{~B} \mathrm{bcd}$ & $83.56 \mathrm{~A}$ abc \\
\hline Q13-31 & $43.77 \mathrm{~B}$ de & $88.44 \mathrm{~A} a b$ & $48.44 \mathrm{~B}$ cde & $90.67 \mathrm{~A} \mathrm{ab}$ \\
\hline Q2014 & $47.55 \mathrm{~B}$ de & $91.77 \mathrm{~A} a b$ & 52.22 B cde & $91.11 \mathrm{~A} \mathrm{ab}$ \\
\hline Average & 53.25 & 82.52 & 57.15 & 84.68 \\
\hline
\end{tabular}

In the first count, at 5 days, the genotypes Q13-24, Q13-01 and Q2014 showed a better quality of conventional seeds and lower germination rates for agroecological ones (Table 6), being that at 8 days kept this behavior, allowing to infer that these genotypes are not proper for agroecological cultivation. However, no genotype with superior performance for agroecological seeds and low performance for conventional seeds was observed.

Evaluating the quality of coriander seeds (Coriandrum sativum L.) coming from organic and conventional system, Silva et al. (2012) concluded that the seed's potential was not influenced by the crop system. Rodrigues et al. (2007) report that the yield potential and the quality of onion seeds in the agroecological and conventional seeds are similar. Opposing the results observed in the literature, it is observed that the quinoa genotypes had an average performance $90 \%$ superior for germination when seeds came from the conventional crop, allowing to infer that, in a general way, the crop system directly influenced the seeds' quality.

The agroecological production of the Q13-21 genotype presented seeds with germination superior to the genotypes "Q-seleção", Q13-02, Q13-03, Q13-06, Q13-17, Q13-01, Q13-24, Q13-18, Q13-10, Q13-04, Q13-20, Q13-31 and Q2014.

The genotype Q13-24 generated seeds with higher germination than the genotypes Q13-02, Q13-03 and Q1306 when their seeds were produced under the conventional system.

The genotype Q13-21 showed the seed germination percentage above 80\% independently of the crop system used to produce these seeds.

The quinoa genotypes "Q-seleção", Q13-01, Q13-04, Q13-10, Q13-17, Q13-18, Q13-20, Q13-23, Q13-24, Q1331 and Q2014, when produced in conventional system presented more than $80 \%$ of seed germination which was not observed when the seeds from these genotypes came from the agroecological system.

\section{References}

APG III. 2009. An update of the Angiosperm Phylogeny Group classification for the orders and families of flowering plants: APG III. Botanical Journal of the Linnean Society 64:105-121.

Bhargava A et al. 2007. Genetic diversity for morphological and quality traits in quinoa (Chenopodium quinoa Willd.) germplasm. Genetic Resources and Crop Evolution 54:167-173.

Brasil. 2009. Ministério da Agricultura e Reforma Agrária. Regras para Análise de Sementes. Brasília: MAPA/ACS, 399 p.

Casaroli D et al. 2006. Health and physiological quality of 'Menina Brasileira' squash seeds. Fitopatologia Brasileira 31:158-163.

Ceccato D et al. 2011. Fuentes de tolerância al brotado pre-cosecha en quinoa (Chenopodium quinoa Willd.). Efecto de las condiciones ambientales sobre el nível de dormición. Análisis de Semillas 59:50-55.

Christiansen JL et al. 2010. Photoperiodic effect on flowering and seed development in quinoa (Chenopodium quinoa Willd.). Acta Agriculturae Scandinavica, Section B-Soil \& Plant Science 60:539-544.

Cruz CD. 2013. Genes: a software package for analysis in experimental statistics and quantitative genetics. Acta Scientiarum. Agronomy 35:271-276. 
Jacobsen ES and Christiansen JL. 2016. Some agronomic strategies for organic quinoa (Chenopodium quinoa Willd.). Journal of Agronomy and Crop Science 202:454-463.

James LEA. 2009. Quinoa (Chenopodium quinoa Willd.): composition, chemistry, nutritional, and functional properties. Advances in Food and Nutrition Research 58:1-31.

Nowak V et al. 2016. Assessment of the nutritional composition of quinoa (Chenopodium quinoa Willd.). Food Chemistry 193:47-54.

Peterson A and Murphy K. 2015. Tolerance of lowland quinoa cultivars to sodium chloride and sodium sulfate salinity. Crop Science 55:331338.

Pulvento $\mathrm{C}$ et al. 2010. Field trial evaluation of two Chenopodium quinoa genotypes grown under rain-fed conditions in a typical Mediterranean environment in south Italy. Journal of Agronomy and Crop Science 196:407-411.

Repo-Carrasco-Valencia R et al. 2010. Flavonoids and other phenolic compounds in Andean indigenous grains: Quinoa (Chenopodium quinoa), kañiwa (Chenopodium pallidicaule) and kiwicha (Amaranthus caudatus). Food Chemistry 120:128-133.

Rodrigues APD et al. 2007. Onion seed production in conventional and transition agroecological systems. Revista Brasileira de Sementes 29:107-110.

Rosa M et al. 2009. Low-temperature effect on enzyme activities involved in sucrose-starch partitioning in salt-stressed and salt-acclimated cotyledons of quinoa (Chenopodium quinoa Willd.) seedlings. Plant Physiology and Biochemistry 47:300-307.

Silva MAD et al. 2012. Evaluation of force of coriander (Coriandrum sativum L.) seeds from the organic and conventional systems. Revista Brasileira de Plantas Medicinais 14:192-196.

Souza FFJ et al. 2016. Physiological quality of quinoa seeds submitted to different storage conditions. African Journal of Agricultural Research 11:1299-1308.

Spehar CR et al. 2015. Advances and challenges for quinoa production and utilization in Brazil chapter: 6.4.2., pp. 562-583. In: Bazile D et al. (Eds.). State of the art report on quinoa around the world in 2013. Oficina Regional de la FAO para América Latina y el Caribe: Santiago, Chile. 605 p.

Strenske A et al. 2015. Quinoa seed germination of different storage periods. Scientia Agraria Paranaensis 14:286-290.

Sun $Y$ et al. 2014. Sensitivity of two quinoa (Chenopodium quinoa Willd.) varieties to progressive drought stress. Journal of Agronomy and Crop Science 200:12-23.

Vega-Gálvez A et al. 2010. Nutrition facts and functional potential of quinoa (Chenopodium quinoa Willd.), an ancient Andean grain: a review. Journal of the Science of Food and Agriculture 90:2541-2547. 